\title{
Karel Kazbunda 1888-1982
}

Karel Kazbunda, the Nestor among Czech historians and archivists in this and perhaps any other century, died on June 7, 1982, at the age of ninety-four. He was probably the last surviving member of the outstanding school of Czech historians who received their training as subjects of the Habsburg empire.

He was born on January 24, 1888, in Jičín, a regional center in northcentral Bohemia. With a dissertation titled, "Zahraniční politika Rakouska před valkou francouzskopruskou (Otázka allianční)" [The Foreign Policy of Austria before the Franco-Prussian War (the alliance question)], he earned the degree of doctor of philosophy at the Charles-Ferdinand Czech University in Prague in 1911-12 under Josef Pekař and Josef Šusta. After the founding of the Czechoslovak Republic, Kazbunda worked in the archives of the ministry of foreign affairs. He participated in the commission that arranged for the removal of portions of the former Habsburg imperial archives from Vienna to Prague and, by this, he gained a profound knowledge of their contents. In the 1920's he published numerous articles in Český časopis historický [The Czech Journal of History] and Časopis archivni skoly [Journal of the Archival School] which described the materials, their mode of organization, and the possibilities for research in the newly established Czechoslovak state archives.

The scholarly themes of Kazbunda's lifetime are apparent in his historical essays from that period. They include the revolution of 1848 , the career of pioneer Czech journalist and political activist Karel Havliček, internal Bohemian politics during the Austrian constitutional era, and imperial foreign policy. Two of his important early books were Pout' Čechü do Moskvy 1867 a rakouská diplomacie [The Pilgrimage of the Czechs to Moscow in 1867 and Austrian Diplomacy] (1924) and his Habilitationsschrift, published as České hnutí rok 1848 [The Czech Movement of 1848] (1929), which became a standard work. In the reviewers' acclaim for his scholarship, however, they struck a critical note, complaining that he was relying excessively on Austrian official documents and neglecting domestic Czech sources such as personal correspondence, memoirs, and evidence from social and cultural life. Kazbunda, to some extent, heeded these criticisms in later writings, but he never fully emancipated himself from reliance on the official archival sources he knew so well and which gave an impressive factual quality to his work.

In 1930 Kazbunda was appointed docent in modern Czechoslovak history at Charles University. Significant writings continued to flow from his pen, among them "Česká politika na počátku éry Belcrediho" [Czech Policy 
at the Beginning of the Belcredi Era] (1933) and the detailed "Krise české politiky a vídeňské jednání o t. zv. punktace roku 1890" [The Crisis in Czech Policy and the Vienna Negotiations over the so-called Punktation of 1890] (1934-1935), both of which appeared in Český časopis historický. His close association with the interwar régime probably dampened his career and publishing opportunities after 1948. For twenty years very little of his work appeared in print until he was able to follow up an early study of the historical discipline at Prague University (published in a Festschrift for Pekar̆ in 1930) with his well-received Stolice dějin na pražské universitě [The Chair in History at Prague University] (3 vols., 1965-68).

Kazbunda retired from the university in 1949 , never having risen above the rank of docent because of the revolutionary changes brought about by the war, the closing of the university under the Nazis, and the political upheaval after the war. In retirement he worked as archivist in the ministry of foreign affairs and until his death lived at the family home in Jičín. Although he was eighty when the last volume of his Stolice dějin appeared, he continued to conduct research and write without abatement. In the early 1970's he completed in meticulous handwriting a thousand-page draft of a biography of Havlíček, which he is reported to have considered his finest effort. He also wrote about Karel Sabina and J. K. Tyl, political publicists and writers from the mid-nineteenth century. Returning to the administrative records of Austria, he produced a massive study of Czech-German relations in the immediate pre-1914 years, with emphasis on the dissolution of the Bohemian diet on July 26, 1913. It is unlikely that any of these manuscripts will ever be published, to the great loss of historical scholarship. Almost until his very last days, Kazbunda continued to study and write. Unperturbed by the whirlpool of politics, he apparently found in painstaking scholarship the purpose and solace of his long life. 